\title{
Effectiveness of Liquid Probiotics from Organic Waste to Treat Hotel Domestic Waste
}

\author{
Jahruddin $^{1 *}$, Badrus Zaman ${ }^{2}$, Sri Sumiyati ${ }^{3}$ \\ 1,2,3 Faculty of Engineering, Department of Environmental Engineering, \\ Diponegoro University, Semarang, Indonesia. \\ *Corresponding email: jq291182@gmail.com
}

Received: December 4, 2021

Accepted: December 30, 2021

\begin{abstract}
With the hotel business rapidly growing, the emergence of pollution is increasing from year to year, including wastewater. Several processes are available to treat domestic wastewater. One of the biological processes that will be used is by using probiotics. This study aims to analyze the effectiveness of liquid probiotics from organic waste to treat domestic wastewater. The parameters observed in this study were $\mathrm{PH}, \mathrm{BOD}_{5}, \mathrm{COD}$, TSS, oil and fat, ammonia, and total coliform. In this study, two types of treatment were applied, namely treatment I (liquid waste only) and treatment II (probiotics + wastewater from the WWTP aeration process). The volume of the wastewater is varied in treatment II. The mixing contact times used were 24 hours, 42 hours, and 72 hours. The best result is seen in Ammonia with 24 hours of aeration of wastewater and a mixture of $150 \mathrm{ml} /$ liter probiotics. The improvements that meet the government's threshold value (TLV) are total coliforms in experiments with wastewater aeration for 42 hours and a mixture of $100 \mathrm{ml} /$ liter probiotics. The total coliforms improvement was seen in the 72-hour aeration experiment of wastewater and a mixture of $100 \mathrm{ml}$ of probiotics.
\end{abstract}

Keywords: probiotics, domestic hotel wastewater, organic waste, aeration, waste water treatment

\begin{abstract}
Abstrak
Seiring dengan bisnis hotel yang berkembang pesat, polusi semakin meningkat dari tahun ke tahun, termasuk air limbah. Beberapa proses tersedia untuk mengolah air limbah domestik. Salah satu proses biologis yang akan digunakan adalah dengan penggunaan probiotik. Penelitian ini bertujuan untuk menganalisis efektivitas probiotik cair dari sampah organik untuk mengolah air limbah domestik. Parameter yang diamati dalam penelitian ini adalah $\mathrm{PH}, \mathrm{BOD}_{5}, \mathrm{COD}$, TSS, minyak dan lemak, amoniak, dan total koliform. Pada penelitian ini dilakukan dua jenis perlakuan, yaitu perlakuan I (limbah cair saja) dan perlakuan II (probiotik + air limbah dari proses aerasi IPAL). Volume air limbah divariasikan pada perlakuan II. Waktu kontak pencampuran yang digunakan adalah 24 jam, 42 jam, dan 72 jam. Hasil terbaik terlihat pada parameter amoniak dengan aerasi 24 jam air limbah dengan campuran probiotik $150 \mathrm{ml} /$ liter. Perbaikan yang memenuhi ambang batas pemerintah (TLV) adalah total koliform pada percobaan dengan aerasi air limbah selama 42 jam dengan campuran probiotik $100 \mathrm{ml} /$ liter. Peningkatan total koliform terlihat pada percobaan aerasi 72 jam air limbah dengan campuran $100 \mathrm{ml}$ probiotik.
\end{abstract}

Kata Kunci: probiotik, air limbah domestik hotel, sampah organik, aerasi, pengolahan air limbah

\section{Introduction}

The industrialization process in a country causes changes in various fields of life. Three important factors play a dominant role, namely: changes in the pattern of people's income, the work system of the population, and waste that is disposed of in the surrounding environment. Waste discharged into the environment comes from various activities, such as textile factories that produce carcinogenic dyes. Gold mining waste, one of the causes of mercury pollution in river sediments, can occur due to natural processes (weathering of mineral rocks), traditional gold extraction (amalgamation), and industrial processes that use raw materials containing mercury [1]. As well as the development of the city causes the growth of hotels, which later increase the amount of domestic liquid waste.

The increase in the number of hotels in Semarang City has a negative impact that cannot be considered simple, namely an increase in the generation of waste, especially organic waste and liquid waste. This waste problem needs to be addressed properly because it can cause environmental pollution both in drainage and on the surface of the receiving land which also will impact humans and other living things. Environmental pollution due to waste generated by hotels will be even greater if hotel waste disposal is 
carried out directly without prior treatment. This can result in groundwater being inappropriate for consumption and soil contamination. In addition, hotel wastewater can also cause odors that can disturb the comfort of the surrounding environment. Sewage treatment system is very important to be owned by every hotel. Through appropriate processing, the wastewater can be treated so that the hotel waste will not be dangerous due to the concentration of pollutants has decreased to minimize the negative impacts caused by pollution. Wastewater treatment generally does use three kinds of processes, namely the processes of physics, chemistry, and biology. One of the biological processes is by addition or combination with probiotics.

In the hotel industry, generated waste consists of several types, namely (a) Organic waste, the source comes from the residual of the kitchen, restaurant, garden processes; (b) Inorganic waste, the biggest source comes from wedding activities or events, hotel rooms; (c) Domestic wastewater, the largest source comes from the use of bathrooms by hotel guests; and (d) Hazardous Waste Materials, the biggest source of equipment maintenance activities. Of the waste produced, the largest volume of waste is organic waste from the kitchen and domestic liquid waste. The resulting organic waste is managed by being collected in organic waste bins. The resulting domestic liquid waste is managed using WWTP (Wastewater Treatment Plant).

One of the efforts to manage liquid waste is to use a biological treatment unit. Biological treatment is the decomposition of organic matter contained in water by microorganisms so that simple chemicals in the form of elements and minerals are readily and safely disposed of into the environment. The purpose of biological wastewater treatment is to remove and stabilize dissolved organic pollutants carried out by microorganisms. In recent years, there has been increasing interest in the use of probiotic bacteria in aquaculture and in improving water quality. Because probiotic bacteria directly absorb or decompose organic materials or toxic substances in the water, thereby improving water quality [2].

\section{Materials and Methods}

This study was held in March 2021, at Patra Semarang Hotel and Convention. Organic waste that comes from the kitchen will be used as a base for making probiotic liquids. The trash from probiotics process can be used to make compost. However, this article will focus on the use of probiotics for domestic wastewater treatment at WWTP. Probiotics are live microorganisms, which in sufficient quantities to provide benefits. In this study, probiotics were produced by utilizing some organic waste from the kitchen through the process of decay. An experiment was carried out on the addition of probiotic bacteria to the aerobic unit, but using a laboratory scale to assess changes in the quality of waste water that occurs. This study used multiple variable timing and number of probiotics. The probiotics are mixed with $1000 \mathrm{ml}$ of liquid waste sample.

\section{Making Probiotics}

In this study, the probiotic used is self-produced probiotics by using organic waste materials from a hotel. The materials and equipment used for the manufacture of probiotics are as follows.

Table 1. Experimental materials and equipment

\begin{tabular}{lll}
\hline \multicolumn{1}{c}{ Substance } & \multicolumn{1}{c}{ Equipment } \\
\hline 1. Sugar & 1. Plastic bucket / drum Capacity of 20 liters: 1 Pc \\
2. Rice flour & 2. Gauze for the bucket cover: sufficiently \\
3. Broiler chicken feed / BR & 3. Rubber tires for fastening: sufficiently \\
4. Yeast tape & 4. Small Aquarium Aerator : 1 Pc \\
5. Pineapple rind / pineapple fruit & \\
6. Raw tuna & \\
7. Yakult & \\
8. Ripe coconut water & \\
9. Clean Water (eg: Mineral Water, other than & \\
\hline
\end{tabular}

Source: Author's research and analysis (2021)

First, all the ingredients above are mixed into a plastic bucket or drum until blended. Attach the hose to the submerged aerator tank until the bottom of the bucket or drum and close the bucket or drum with gauze to avoid dirt into the container. Aeration for $7 \times 24$ hours non-stop. On the $7^{\text {th }}$ day probiotics are ready for use. 


\section{Existing Type of Wastewater Treatment}

The current domestic wastewater treatment uses physical, biological and chemical treatment. The processing units used are Equalizing, Aeration, Sedimentation, Clarification. Each processing unit consists of 2 (two) units that operate in parallel, this is to anticipate if there is damage to one unit, the processing can still run using other units. Figure 1 is a picture of the existing processing unit:

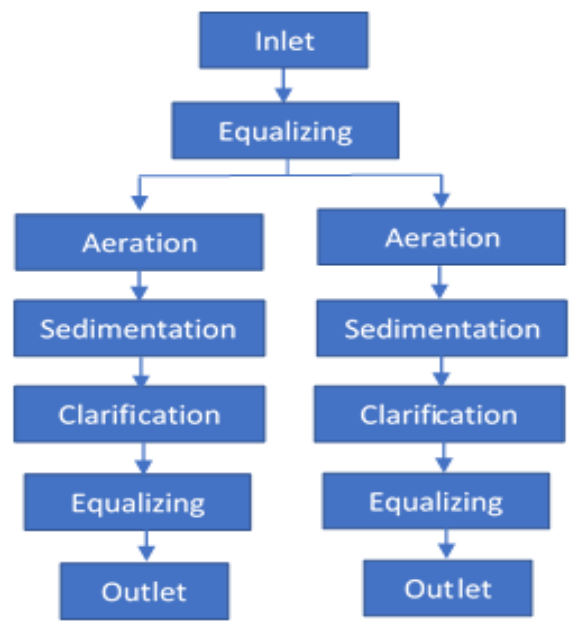

Figure 1. Existing processing unit of WWTP Source: Author's research and analysis (2021)

Domestic wastewater that is treated at the WWTP is black water which comes from the use of the hotel guests' bathrooms. The amount of wastewater generated per day on average $36 \mathrm{~m}^{3}$ per day.

Table 2. Laboratory test results initial characteristics of wastewater on March 16, 2021

\begin{tabular}{lllll}
\hline No. & Parameters & Unit & Laboratory Analysis Results & TLV \\
\hline 1. & pH & - & 7,54 & $6,0-9,0$ \\
2. & BOD $_{5}$ & $\mathrm{Mg} / \mathrm{L}$ & 130 & 30 \\
3. & COD & $\mathrm{Mg} / \mathrm{L}$ & 283,33 & 100 \\
4. & TSS & $\mathrm{Mg} / \mathrm{L}$ & 87,83 & 30 \\
5. & Oil \& Fat & $\mathrm{Mg} / \mathrm{L}$ & 10 & 5 \\
6. & Amonia & $\mathrm{Mg} / \mathrm{L}$ & 30,31 & 10 \\
7. & Total Coliform & Total/100ML & 2000 & 3000 \\
\hline
\end{tabular}

Source: Authour's research and analysis (2021)

From the laboratory test results above, it can be seen that several parameters have not met the environmental quality standards set by the Government in accordance with the Regulation of the Minister of Environment and Forestry of the Republic of Indonesia Number: P.68/Menlhk/Sekjen/Kum/8/2016 about Domestic Wastewater Quality Standards, which include: $\mathrm{BOD}_{5}, \mathrm{COD}$, TSS, oils \& fats, and ammonia, while the other two parameters that meet the requirements are $\mathrm{pH}$ and total coliform.

\section{Experiment}

In this study a few variable samples. The stages were carried out as following, domestic liquid waste is taken from the WWTP in the aeration unit as much as $1000 \mathrm{~mL}$ per sample package. Then, the sample is poured into a plastic container made from Polypropylene. The aerator hose is installed and the use is shared with an air flowrate of $2.5 \mathrm{~L} / \mathrm{min}$, so that each container gets an air intake of $1.25 \mathrm{~L} / \mathrm{min}$. Probiotics is poured as much as a predetermined variable volume. The aerator is turned on in accordance with the time varied. Samples were taken by the method of collection in accordance with the Indonesian National Standard SNI 6989-59-2008 number 59 regarding the Method of Sampling of Wastewater. 


\section{Results and Discussion}

The research results are contained in figures below:

Table 3. Results of experiments with $1000 \mathrm{~mL}$ wastewater samples and probiotic mixture

\begin{tabular}{|c|c|c|c|c|c|c|c|c|c|c|c|c|c|c|}
\hline \multirow{2}{*}{$\begin{array}{l}\text { Parameter / } \\
\text { Probiotic Dose }\end{array}$} & \multirow{2}{*}{ BML* } & \multirow{2}{*}{$\begin{array}{c}24 \text { hour } \\
0\end{array}$} & \multicolumn{3}{|c|}{24 hour } & \multicolumn{3}{|c|}{24 hour } & \multicolumn{3}{|c|}{42 hour } & \multicolumn{3}{|c|}{72 hour } \\
\hline & & & 300 & 400 & 500 & 50 & 100 & 150 & 50 & 100 & 150 & 50 & 100 & 150 \\
\hline PH & $6,0-9,0$ & 7,54 & 5,47 & 5,1 & 4,91 & 7,39 & 7,29 & 6,86 & 7,67 & 7,76 & 7,35 & 7,23 & 7,56 & 7,55 \\
\hline TSS & 30 & 130 & 172 & 154 & 214 & 112,7 & 114,7 & 138,5 & 283,3 & 121,8 & 338 & 67 & 169 & 136,3 \\
\hline COD & 100 & 283,3 & 983,33 & 980 & 990 & 163,3 & 530 & 833,33 & 166,67 & 236,67 & 443,33 & 116,67 & 280 & 256,67 \\
\hline $\mathrm{BOD}_{5}$ & 30 & 87,83 & 304,83 & 303,8 & 306,9 & 50,63 & 164,3 & 258,33 & 51,67 & 73,37 & 137,43 & 36,17 & 86,8 & 79,57 \\
\hline Ammonia & 10 & 30,31 & 23,92 & 27,85 & 24,44 & 28,4 & 23,04 & 15,81 & 30,84 & 33,29 & 31,1 & 23,41 & 31,23 & 30,62 \\
\hline Oil and Fat & 5 & 10 & 9 & 9 & 16 & 14 & 13 & 13 & 13 & 16 & 15 & 23 & 10 & 13 \\
\hline Total Coliform & 3000 & 2000 & 6000 & 4600 & 3100 & 4200 & 9100 & 8300 & 6200 & 2200 & 7700 & 6400 & 1700 & 4300 \\
\hline
\end{tabular}

Source: Author's research and analysis (2021)

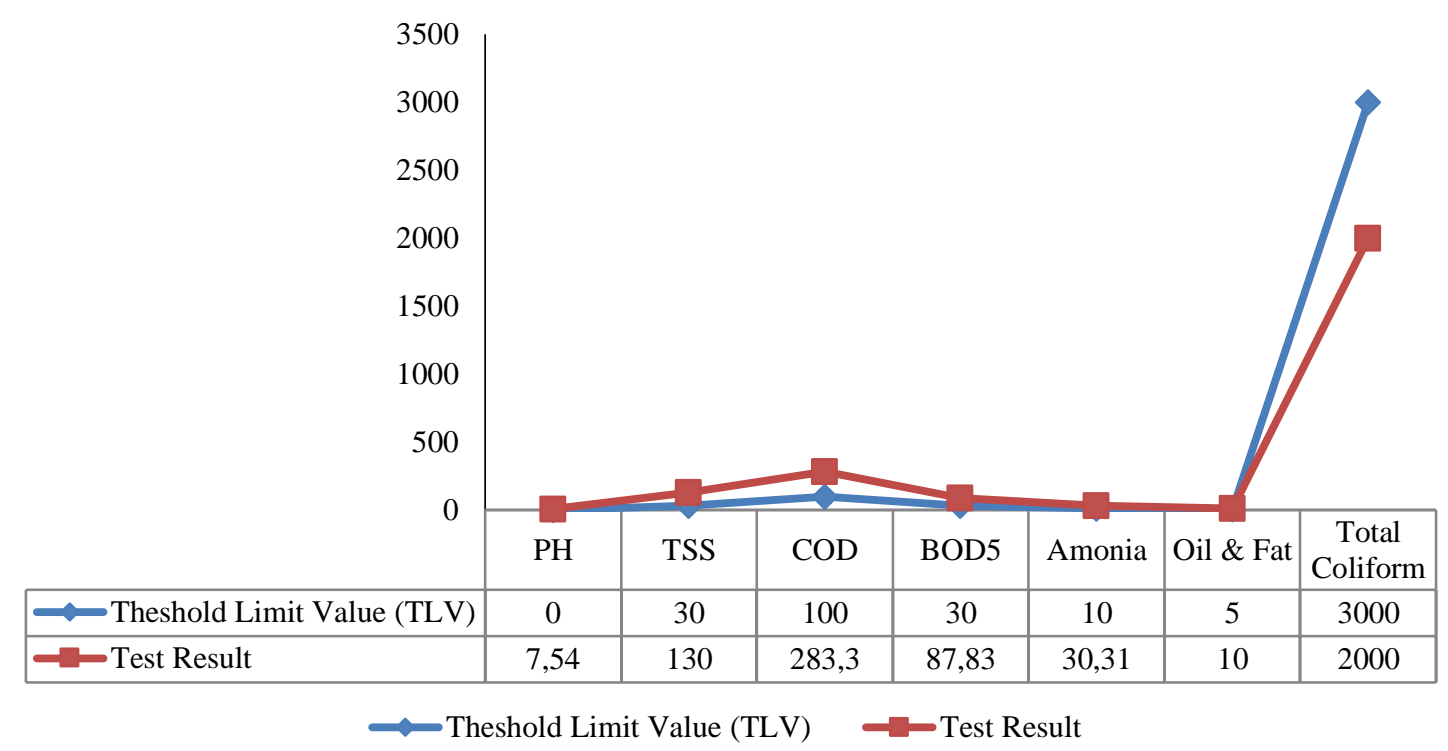

Figure 2. Results of 24-hour aeration experiments with $1000 \mathrm{~mL}$ wastewater samples and $0 \mathrm{~mL}$ probiotic mixture Source : Author's research and analysis (2021)

Figure 2 shows that aeration carried out for 24 hours without a mixture of probiotic do not show results parameters that meet threshold limit value (TLV) set by the Government except for total coliform. 


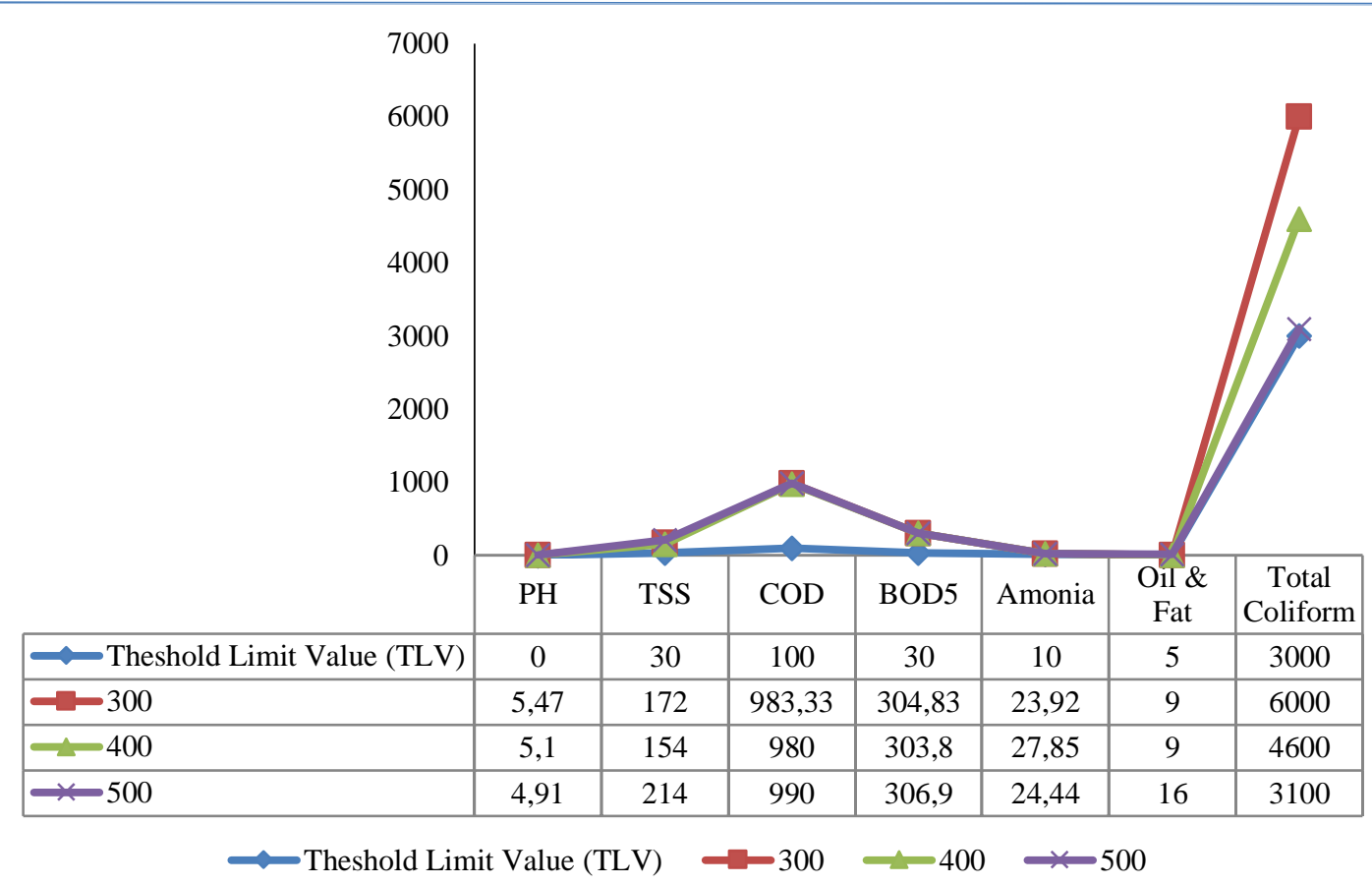

Figure 3. Results of 24-hour aeration experiments with $1000 \mathrm{~mL}$ wastewater samples and $300 \mathrm{~mL}, 400 \mathrm{~mL}, 500 \mathrm{~mL}$ probiotic mixtures

Source: Author's research and analysis (2021)

Figure 3 shows that the aeration is done for 24 hours with a variable mixture of probiotics respectively $300 \mathrm{~mL}, 400 \mathrm{~mL}, 500 \mathrm{~mL}$ do not show the results of the parameters that meet the threshold limit values (TLV) established by the Government, but there was improvement in $\mathrm{BOD}_{5}$, ammonia, oil and fat, compared to the experiment in Figure 2.

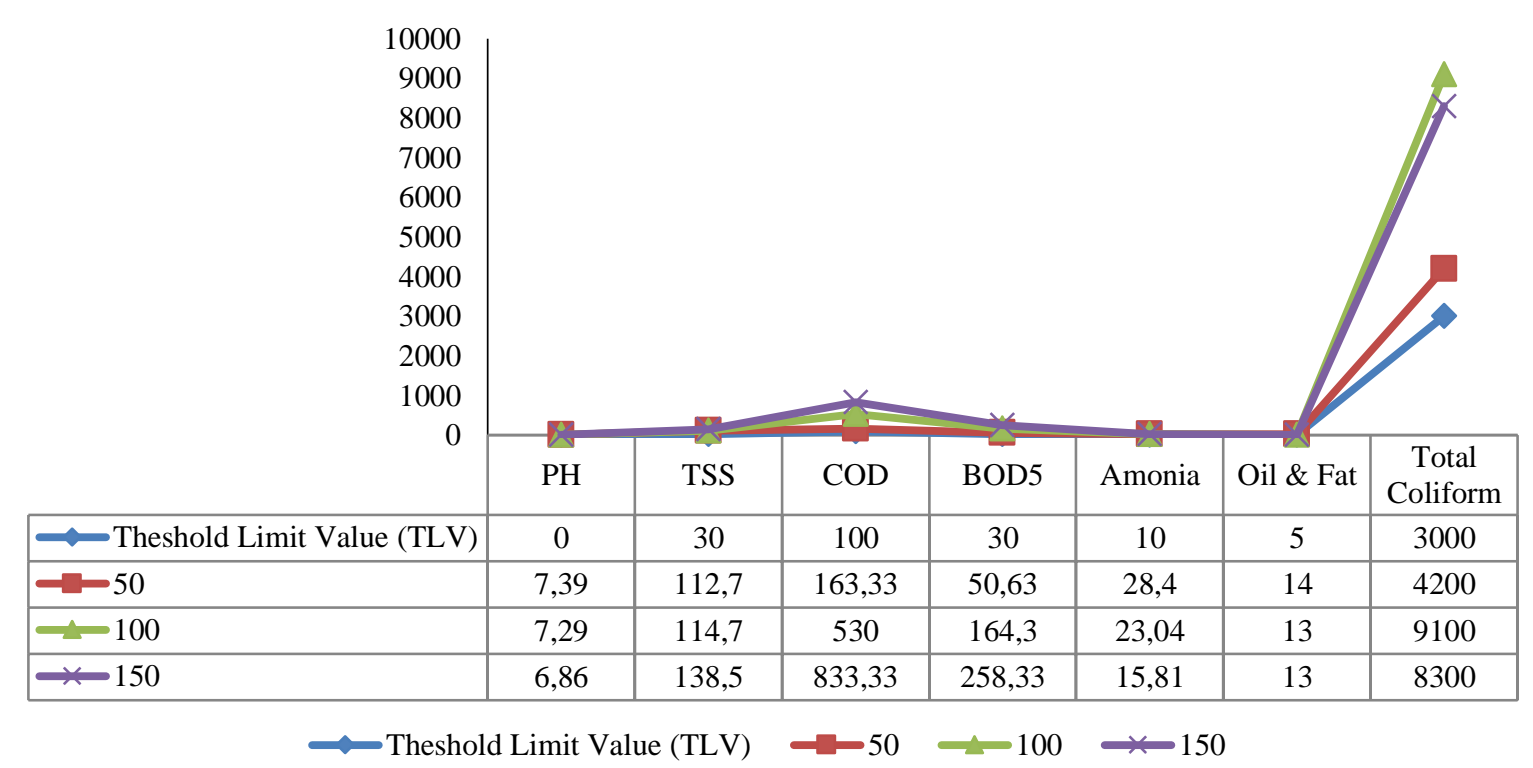

Figure 4. Results of 24-hour aeration experiments with $1000 \mathrm{~mL}$ wastewater samples and $50 \mathrm{~mL}, 100 \mathrm{~mL}, 150 \mathrm{~mL}$ probiotic mixtures

Source: Author's research and analysis (2021)

In Figure 4, it can be seen that the aeration carried out for 24 hours with a variable probiotic mixture of $50 \mathrm{~mL}, 100 \mathrm{~mL}, 150 \mathrm{~mL}$ respectively do not show the results of the parameters that meet the threshold limit value (TLV) set by the Government, but there is an improvement in TSS compared to experiment in Figure 2 and Figure 3. 


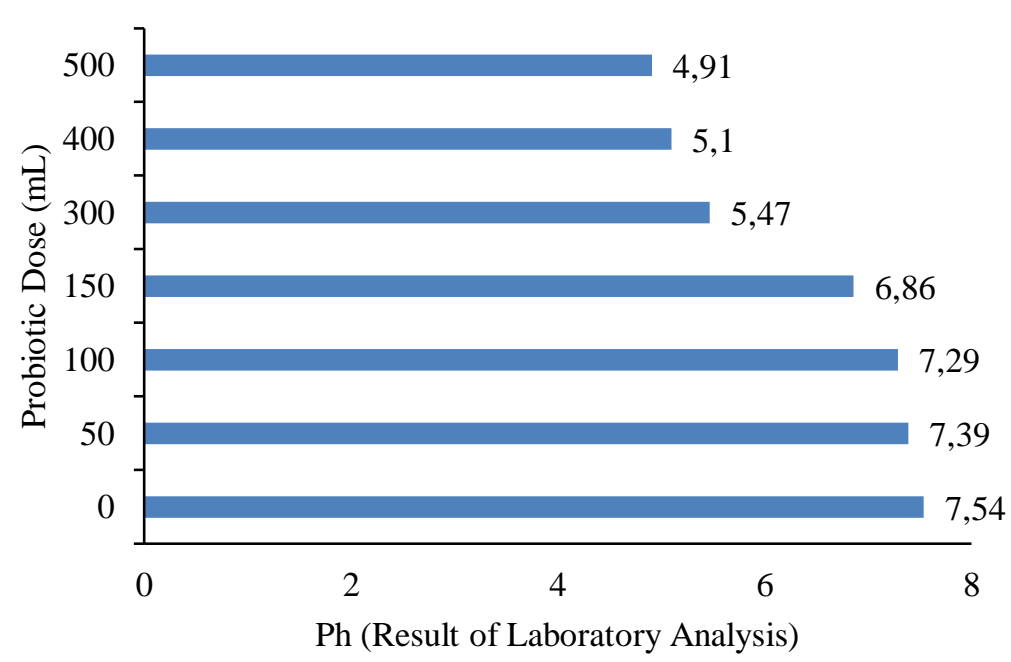

Figure 5. $\mathrm{pH}$ Results of 24-hour aeration experiments with $1000 \mathrm{~mL}$ wastewater samples and $0 \mathrm{~mL}, 50 \mathrm{~mL}, 100 \mathrm{~mL}, 150 \mathrm{~mL}, 300 \mathrm{~mL}, 400 \mathrm{~mL}, 500 \mathrm{~mL}$ probiotic mixtures

Source: Author's research and analysis (2021)

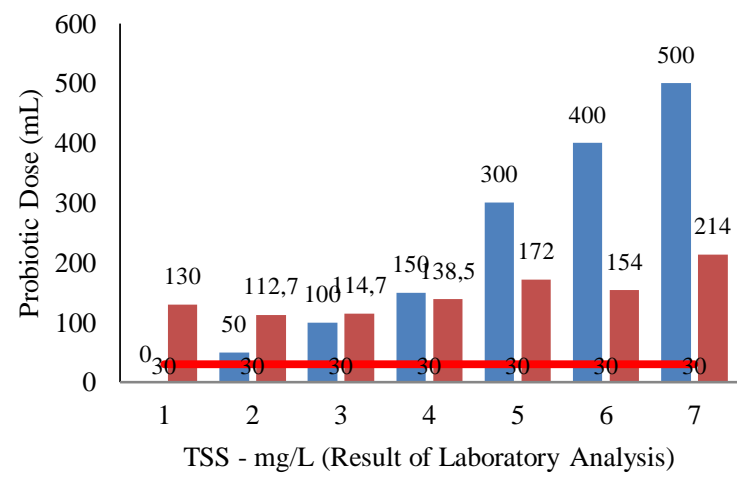

Probiotic Dose Result $\longrightarrow$ Standard

Figure 6. TSS Results of 24-hour aeration experiments with $1000 \mathrm{~mL}$ wastewater samples and $0 \mathrm{~mL}, 50 \mathrm{~mL}$, $100 \mathrm{~mL}, 150 \mathrm{~mL}, 300 \mathrm{~mL}, 400 \mathrm{~mL}, 500 \mathrm{~mL}$ probiotic mixtures

Source: Author's research and analysis (2021)

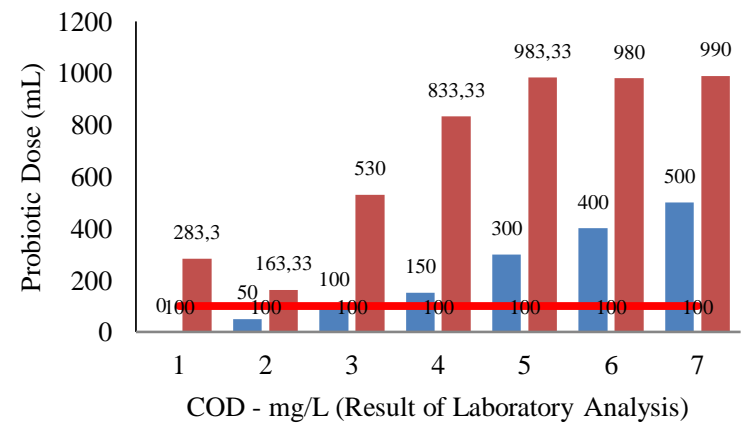

Probiotic Dose Result $\longrightarrow$ Standard

Figure 7. COD Results of 24-hour aeration experiments with $1000 \mathrm{~mL}$ wastewater samples and 0 $\mathrm{mL}, 50 \mathrm{~mL}, 100 \mathrm{~mL}, 150 \mathrm{~mL}, 300 \mathrm{~mL}, 400 \mathrm{~mL}, 500$ $\mathrm{mL}$ probiotic mixtures

Source: Author's research and analysis (2021)

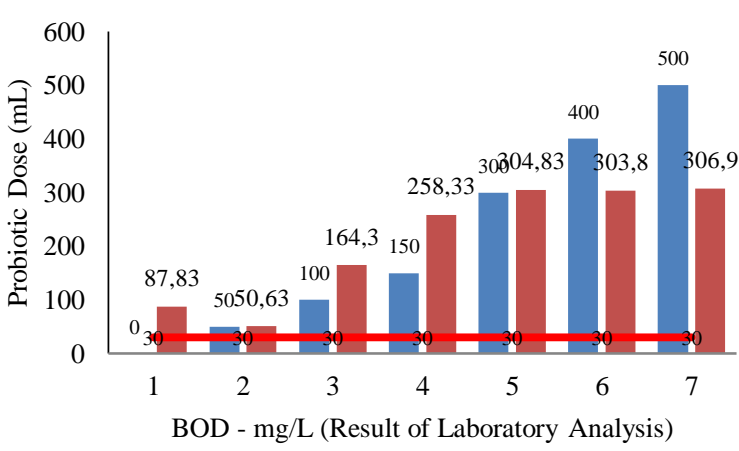

Probiotic Dose Result $\rightleftharpoons$ Standard

Figure 8. $\mathrm{BOD}_{5}$ Results of 24-hour aeration experiments with $1000 \mathrm{~mL}$ wastewater samples and 0 $\mathrm{mL}, 50 \mathrm{~mL}, 100 \mathrm{~mL}, 150, \mathrm{~mL}, 300 \mathrm{~mL}, 400 \mathrm{~mL}, 500$ $\mathrm{mL}$ probiotic mixtures

Source: Author's research and analysis (2021)

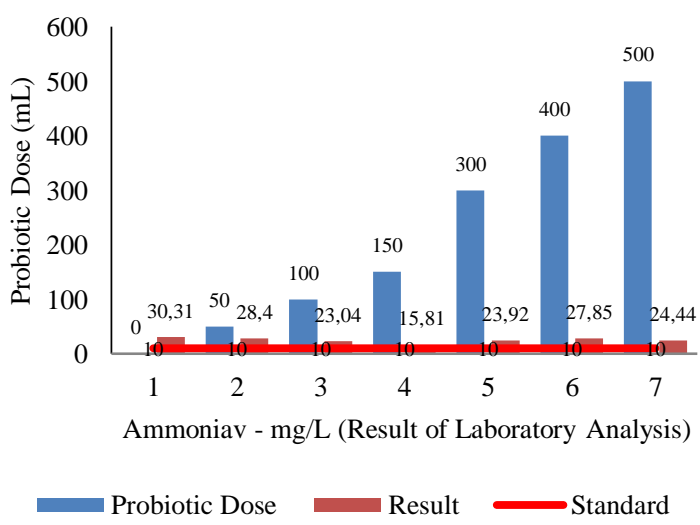

Figure 9. Ammonia Results of 24-hour aeration experiments with $1000 \mathrm{~mL}$ wastewater samples and 0 $\mathrm{mL}, 50 \mathrm{~mL}, 100 \mathrm{~mL}, 150 \mathrm{~mL}, 300 \mathrm{~mL}, 400 \mathrm{~mL}, 500$ $\mathrm{mL}$ probiotic mixtures

Source: Author's research and analysis (2021) 


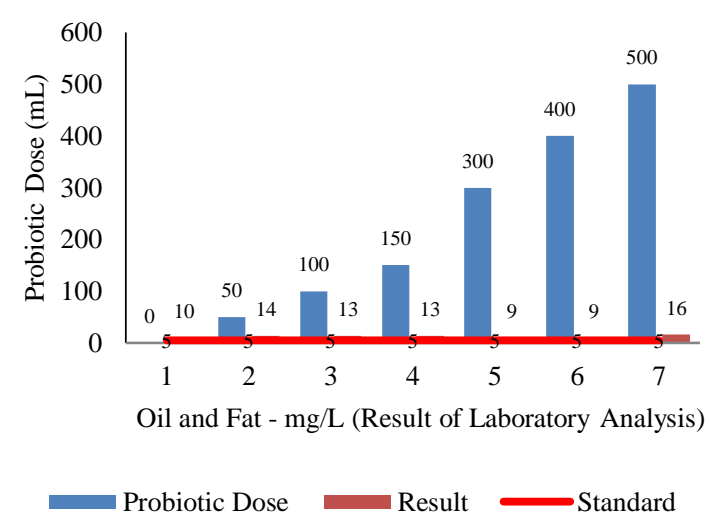

Figure 10. Oil and Fat Results of 24-hour aeration experiments with $1000 \mathrm{~mL}$ wastewater samples and 0 $\mathrm{mL}, 50 \mathrm{~mL}, 100 \mathrm{~mL}, 150 \mathrm{~mL}, 300 \mathrm{~mL}, 400 \mathrm{~mL}, 500$ $\mathrm{mL}$ probiotic mixtures

Source: Author's research and analysis (2021)

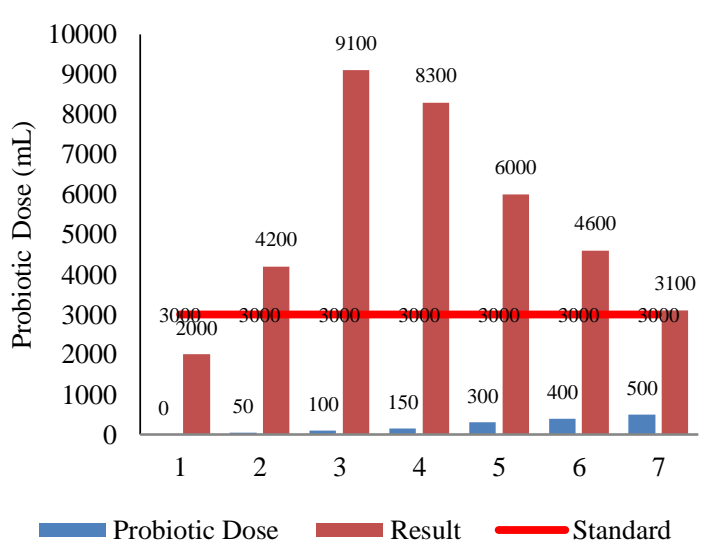

Figure 11. Total Coliform Results of 24-hour aeration experiments with $1000 \mathrm{~mL}$ wastewater samples and 0 $\mathrm{mL}, 50 \mathrm{~mL}, 100 \mathrm{~mL}, 150 \mathrm{~mL}, 300 \mathrm{~mL}, 400 \mathrm{~mL}, 500$ $\mathrm{mL}$ probiotic mixtures

Source: Author's research and analysis (2021)

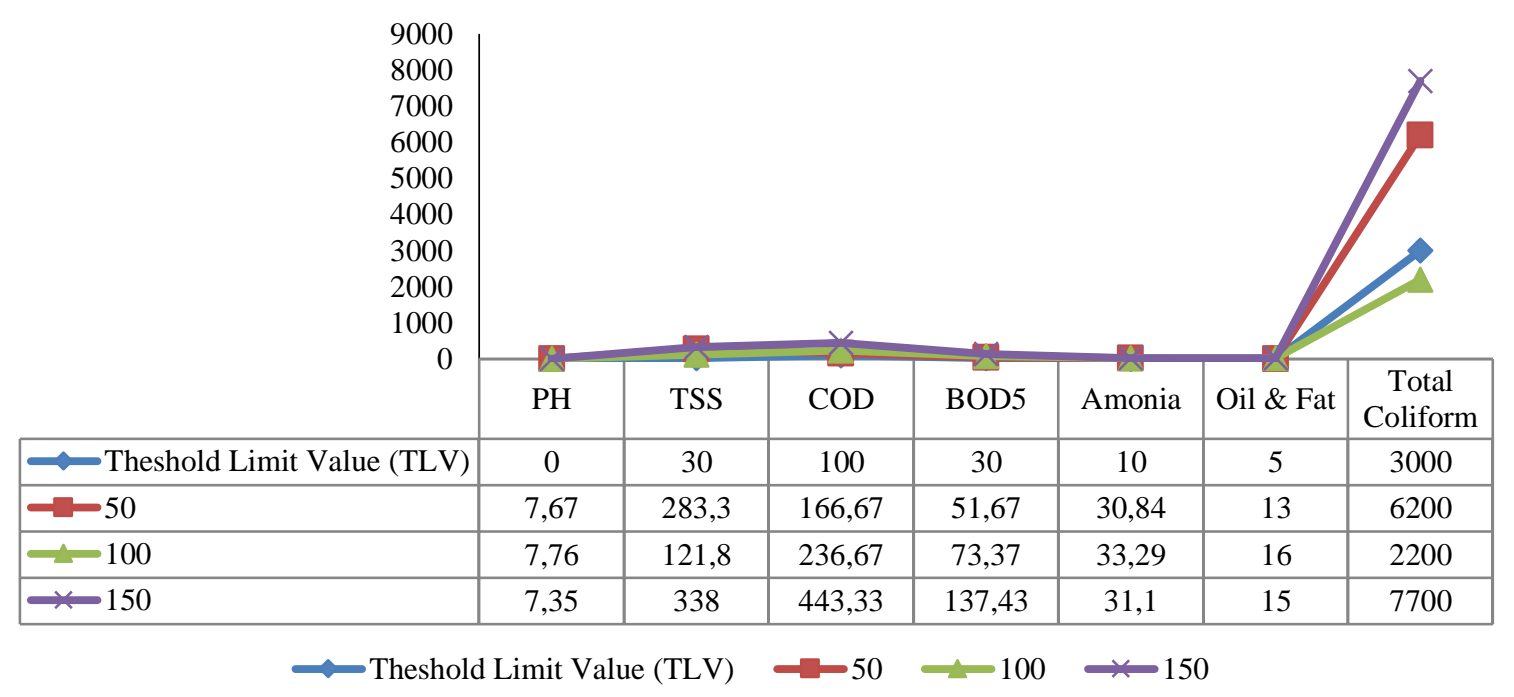

Figure 12. The results of the 42-hour aeration experiment with a $1000 \mathrm{~mL}$ wastewater sample and a $50 \mathrm{~mL}, 100 \mathrm{~mL}, 150 \mathrm{~mL}$ probiotic mixture

Source: Author's research and analysis (2021)

In Figure 12, it can be seen that the aeration carried out for 42 hours with a variable probiotic mixture of $50 \mathrm{~mL}, 100 \mathrm{~mL}, 150 \mathrm{~mL}$ respectively shows that the results of the parameters that meet the threshold value (TLV) set by the Government, are total coliform in the probiotic mixture of $100 \mathrm{~mL}$, but the other parameters do not meet the threshold limit values (TLV). 


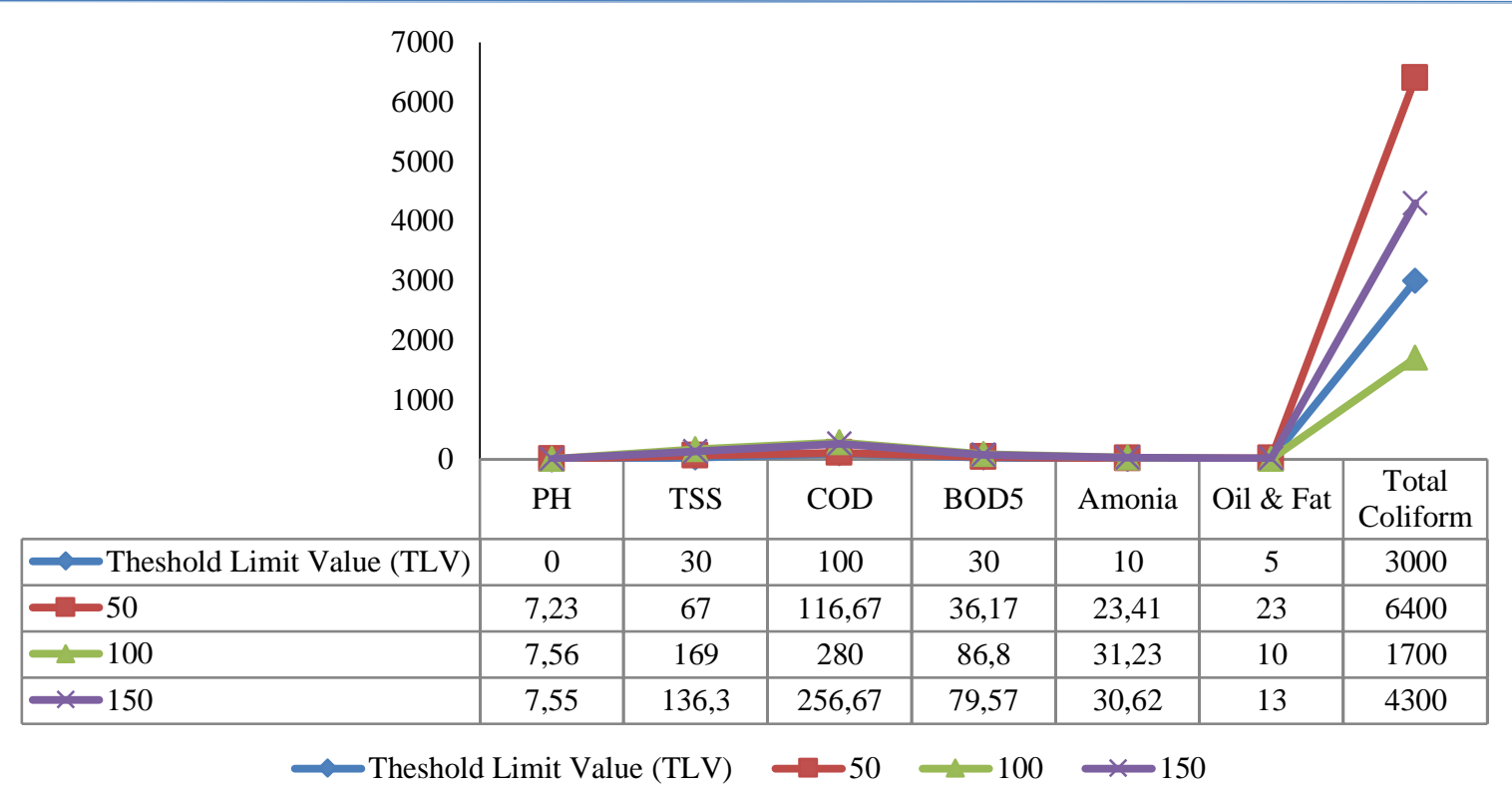

Figure 13. Results of 72 hours aeration experiment with $1000 \mathrm{ml}$ wastewater sample and $50 \mathrm{~mL}, 100 \mathrm{~mL}, 150 \mathrm{~mL}$ probiotic mixture

Source: Author's research and analysis (2021)

Figure 13 shows that the aeration is done for 72 hours with a variable mixture of probiotics, each 50 $\mathrm{mL}, 100 \mathrm{~mL}, 150 \mathrm{~mL}$ show the results of parameters that meet the threshold limit values (TLV) set by the government, is total coliform in a mixture of probiotics as many as $100 \mathrm{ml}$, but other parameters do not meet the threshold value (TLV). It shows almost the same results with the experiment in Figure 12. Based on previous study, the use of probiotics in processed waste oil palm that probiotics can reduce COD, BOD, ammonia, and the whole of pollutant parameters on organic waste with a ratio of 1 liter of probiotics to treat 50-100 liters of liquid waste after 48 hours of use [4].

\section{Conclusion}

The addition of probiotic fluids with a determined volume variation and time variation did not significantly indicate a better change in wastewater quality. The best results were seen in ammonia with aeration for 24 hours of wastewater and a mixture of probiotics as much as $150 \mathrm{~mL} / \mathrm{L}$. And improvements that meet the government's threshold limit value (TLV) are total coliforms in experiments with wastewater aeration for 42 hours and a mixture of probiotics as much as $100 \mathrm{~mL} / \mathrm{L}$.

\section{References}

[1] Abunajwa. 2013."Probiotik dalam Gula Aren": www.b1one.baktinusantara.com.

[2] Divya, M., S. Aanand, A. Srinivasan, B. Ahilan, 2015. "Bioremediation - an Eco Friendly Tool for Effluent Treatment: A Review.” International Journal of Applied Research. 1 (12): 530-537

[3] Divya M. Isolation, 2015. "Characterization and Biodegradation Potential of Bacterial Strains of Seafood Processing Plant Effluent for Bioremediation. M.F.Sc thesis. Tamil Nadu Fisheries University, Thoothukudi.

[4] Devianto, L. A., \& Kardena, E. 2010. Pengaruh Glukosa Terhadap Produksi Biosurfaktan oleh Azotobacter vinelandii dan Pengaruh Biosurfaktan Terhadap Biodegredasi Thp oleh Konsorsium Bakteri Petrofilik. Program Studi Teknik Lingkungan Fakultas Teknik Sipil dan Lingkungan, Institut Pertanian Bogor.

[5] Harsan, Susanto. 2014. "Mengulik Konsep dan Kegunaan Probiotik". Trobos. www.troboslivestock.com

[6] Hendro. Bakteri Probiotik Pengolah Limbah CPO [web page on the internet]. 2014. Available from https://sawitindonesia.com/bakteri-probiotik-pengurai-limbah-cpo/

[7] Irwan Mulyadi, Badrus Zaman, and Sri Sumiyati. Mercury (Hg) concentration of river water and sediment in Tambang Sawah village due to gold mining without permission. Pollution and Waste Management [serial online]. 2020. Available from https://www.e3s- 
conferences.org/articles/e3sconf/abs/2020/62/e3sconf_icenis2020_05021/e3sconf_icenis2020_05021. html

[8] Irmanputhra, Joy. 2015.”Sistem Pengolahan Air Limbah Secara Biologis Modul D: Perencanaan Teknis Unit Pengolahan Air Limbah Pelatihan Perencanaan Teknis Sistem Pengelolaan Limbah Terpusat (SPAL-T) Rentek-D5.” Sanitasi.Net.

[9] Padmavathi, P., K. Sunintha, \& K. Veeraiah. 2012. "Efficacy of Probiotics in Improving Water Quality and Bacterial Flora in Fish Ponds." African Journal of Microbiology Research. 6(49): 7471-7478

[10] Paramita, P. M. Shovitri, \& ND. Kuswytasari. 2012. "Biodegradasi Limbah Organik Pasar dengan Menggunakan Mikroorganisme Alami Tangki Septik". Jurnal Sains dan Seni ITS. 1: 2301-928X

[11] PermenLHK No: P.68/MenLHK/Kum/8/2016 [statute on the Internet]. 2016. Available from: http://jdih.menlhk.co.id/index.php/permenlhk/search

[12] Ravindra, S., S. Pushpendra, \& S. Rajesh. 2014. "Microorganism as a Tool of Bioremediation Technology for Cleaning Environment: A Review. Proceedings of the International Academy of Ecology and Environmental Sciences. 4(1): 1-6.

[13] Ringo E., RE. Olsen, TO. Giftsad, RA. Dalmo, H.Almund dan GI. Hemre. 2010. "Prebiotics in aquaculture". Review Article Aquacultue Nutrition. (16):117-136.

[14] Septiani, D. R. 2016. "Uji Kinetika dan Aktivitas Antibakteri dari Bakteri Biokontrol D2.2 pada Salinitas dan $\mathrm{pH}$ yang Berbeda". Universitas Lampung. Lampung.

[15] Samudro, Ganjar. 2010. "Review On BOD, COD and BOD/COD Ratio: A Triangle Zone for Toxic, Biodegradable And Stable Levels. International Journal of Academy Research. Universitas Diponegoro. Semarang. 